\title{
Viver e envelhecer: trajetórias de vida numa vila paulista (Campinas, 1774-1842).
}

\section{Live and aging: life trajectories in a village of São Paulo (Campinas, 1774-1842).}

\section{Paulo Eduardo Teixeira Antonio Carlos dos Santos}

Universidade Estadual Paulista "Júlio de Mesquita Filho" (Unesp - Campus Marília)

\section{Resumo}

O objetivo desse ensaio é discutir alguns pontos para o avanço das pesquisas que tratam do papel do idoso no passado brasileiro. Para tanto, serão levantadas informações sobre pessoas que nasceram no final dos setecentos, sendo as mesmas acompanhadas por documentos de várias ordens, como inventários, testamentos, listas nominativas e registros paroquiais existentes para a Vila de Campinas, em São Paulo.

Palavras-chave: Velhice; Sociedade; Gênero; Campinas; Pesquisa.

\begin{abstract}
The aim of this essay is to discuss some points for the advancement of research that addresses the role of the elderly in the Brazilian past. Therefore, information was raised about people who were born in the late eighteenth century, accompanied by documents of various orders, such as inventories, wills, nominative lists and existing parish registers for Campinas village, in São Paulo.
\end{abstract}

Keywords: Oldness; Society; Cender; Campinas; Research. 


\title{
|
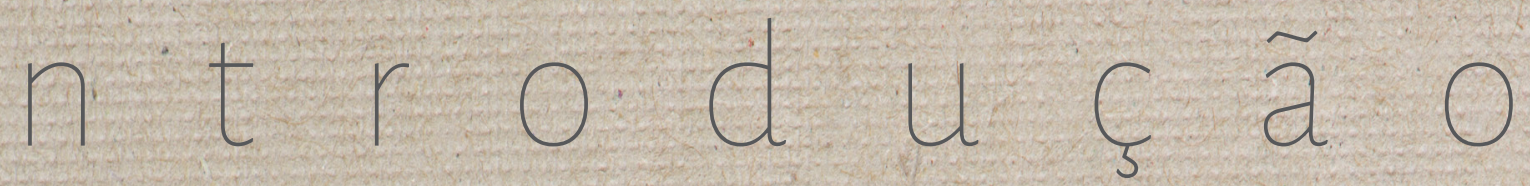

"... não existe um único modo de ser velho e de viver a idade madura, fato também reconhecido pelos especialistas, que alertam para a interação entre o indivíduo e seu contexto, ambos em constante

transformação".

Neusa M. de Cusmão (2007, p. 176)

\begin{abstract}
A partir das mudanças desencadeadas pelas alterações nos padrões demográficos das sociedades capitalistas europeias, que passaram a ocorrer com maior intensidade desde a revolução sexual dos anos de 1960 e implicaram no maior controle da natalidade, bem como na melhoria dos padrões de saúde que afetaram, dentre tantos grupos, os idosos, os quais passaram gradativamente a terem uma expectativa de vida mais longa, notamos que o final do século XX viu emergir novas percepções sobre o envelhecimento das populações, ganhando corpo e espaço e uma atenção especial por parte dos governos e suas políticas públicas voltadas para esse segmento populacional.
\end{abstract}

O estabelecimento, em 1999, do Ano Internacional do Idoso, bem como de uma data comemorativa ao dia internacional dos idosos pelas Nações Unidas? ${ }^{1}$, marcaram as preocupações advindas com o envelhecimento demográfico, que está em um processo de aceleração em quase todos os países do globo, a fim de criar compromissos para o amadurecimento de atitudes e empreendimentos sociais, econômicos e culturais que visem dar destaque ao papel do idoso na sociedade.

Para termos uma noção destas transformações, citamos o caso da Espanha, estudado por Francisco García Conzález (2005), que ao final do século XVIII tinha uma esperança de vida ao nascer que não chegava aos 30 anos de idade, ao passo que, nos anos 1960, essa marca subiu para algo em torno de 50 anos, sendo que na primeira década do século XXI já superava os 75 anos.

Com o alargamento da expectativa de vida e o processo de redução das taxas de natalidade e mortalidade, o resultado está sendo o aumento crescente e significativo dos grupos de idosos.

1 A primeira comemoração do Dia Internacional dos Idosos ocorreu em $1^{\circ}$ de outubro de 1998. 
Por outro lado, após os anos de 1960 o Brasil vem demonstrando a mesma tendência observada nos países desenvolvidos, ou seja, que as taxas de crescimento populacional vếm declinando, embora as taxas de maior aumento populacional tenham sido observadas entre as pessoas com mais de 60 anos de idade, ou seja, a população idosa (CAMARANO, KANSO \& MELLO, 2004, p. 26-27).

Diante disto, o que está sendo posto é o aumento de uma parcela da população composta, de um lado, por pessoas que possuem grande autonomia e capacidade para contribuir para o desenvolvimento econômico e social, desempenhando papéis importantes na família e na sociedade, enquanto que, por outro lado, existem pessoas que não são capazes de desempenhar atividades básicas do cotidiano - muitas delas sem nenhum rendimento próprio -, tornando-se, nesses casos, dependentes do apoio de outros, sejam estes pessoas próximas, como familiares e amigos, ou até instituições de amparo à saúde física e mental, mantidas ou não pelos Estados.

A velhice, no entanto, é um período da vida recoberto por muitos preconceitos e estereótipos vinculados às vulnerabilidades decorrentes do enfraquecimento físico e mental e da proximidade da morte. Tais ideias ainda são muito recorrentes em nossa sociedade, apesar de algumas mudanças significativas no Brasil, como a sanção do Estatuto do Idoso², que procura promover a inclusão social desta parcela da população, exigindo que o Estado garanta seus direitos. Apesar disso, podemos dizer que, em suma, predominam concepções sobre os velhos como "doentes", levando-os a serem tratados como incapacitados (NERI, 2001).

Do ponto de vista histórico, podemos dizer que visões negativas acerça da velhice impediram uma análise mais detida sobre a população idosa no passado, e isto não somente no Brasil. Na introdução do livro A velhice, Simone de Beauvoir (1970), afirmou que, na maioria das vezes, "velho" e "pobre" eram sinônimos, criticando a condição negativa da velhice naquela época, que ainda perdura em nossa sociedade. Já Cuita Grin Debert (1999, p. 45) assinala que a associação da velhice à pobreza ocorreu sobretudo entre 1945 e 1960, época em que houve a generalização do sistema de aposentadorias, colocando os idosos como alvo da assistência social. Evidência deste fato é a grande lacuna existente na produção de pesquisas que focalizam o idoso enquanto objeto central de estudo. No entanto, com a "crise do envelhecimento",

melhores condições de saúde bem como a ampliação da cobertura da Previdência Social em quase todo o mundo têm levado a uma mudança de percepção do que vem a ser a última etapa da vida. A visão de que esta representa um processo de perdas está sendo substituída pela consideração de que aúltima fase da vida éum momento propício para novas conquistas e busca de

2 No Brásil, o Estatuto do Idoso foi instituído pela Lei n. ${ }^{0} 10.741$, de $1^{\circ}$ de outubro de 2003. 
satisfação pessoal. Éa idade do "preenchimento", de acordo com Laslett (1996). (CAMARANO \& PASINATO, 2004, p. 8).

Essa mudança de perspectiva permite aceitar a velhice em termos de "potencialidad", segundo, nos afirma María Teresa Bazo (1992, p. 81) ao destacar a capacidade ou habilidade que permite aos idosos enfrentarem os acontecimentos da vida cotidiana. Potencialidade esta que vai além da concepção decadência/plenitude ou desgraça/gozo, para um modelo que avalia uma pessoa centenária como alguém que possui experiência e capacidade, e ainda pode dar uma contribuição importante para a sociedade.

Assim, ao pensar a velhice nos dias atuais, os estudiosos da família começaram a repensar também o papel de idosos no passado, trazendo novas leituras e interpretações, colocando-os como atores sociais. Estas pesquisas que estão surgindo, especialmente na Europa e nos Estados Unidos, nos instigam a pensar também a sociedade brasileira à luz destas novas questões e dos novos desafios metodológicos para o estudo da velhice, contrariando visões lineares e unidimensionais sobre o significado do tempo.

\section{Conceito de idoso}

Em nossos dias, um pai com a idade de 40 anos pode ser chamado de "velho" por seu filho de apenas 10 anos, e isso pode remeter a uma questão central: o que é ser "velho"? Para essa criança que acha seu pai "velho", as implicações podem ser as mais variadas, como, por exemplo, o não brincar com seu filho, a forma de se vestir, ou ainda alguma característica associada à velhice, como a calvície acentuada ou os cabelos brancos. A idade, em si, não é necessariamente um fator apontado para classificar um sujeito de "velho", mas aspectos que dizem respeito ao lazer, formas de comportamento social e mesmo "marcas" associadas à velhice masculina e feminina podem indicar que "não existe um único modo de ser velho". Por essa razão, Diana Lozano-Poveda (2011, p. 92) afirma que não há uma única idade para a velhice, pois são diferentes a idade cronológica, a idade corporal e a idade social. Tal assertiva remete a uma concepção de velhice que a considera sob três dimensões: a cronológica, medida pelos anos de vida de uma pessoa; a corporal ou biológica, como é chamada por outros autores (OTERO, 2013) e que remete ao estado de saúde de um indivíduo; e, por último, a idade social, que se relaciona com a construção social e histórica da velhice em uma dada sociedade, por meio dos proceśsos de produção e consumo impostos pela mesma. 
A idade, no entanto, tem sido um dos critérios mais utilizados para o estabelecimento da categoria de "idoso", sobretudo porque ela se tornou um critério operacional para a definição estatística da velhice. No Brasil, quando da definição da Política Nacional do Idoso (Lei n 8.842 , de 4 de janeiro de 1994), e no Estatuto do Idoso em seu Artigo $1^{\circ}$, ficou explícito que a pessoa na faixa etária acima dos 60 anos é idosa. Esse princípio parte da pressuposição de que o enveIhecimento é um processo biológico natural e que as capacidades físicas do indivíduo declinam com o passar do tempo, o que leva a uma associação direta entre idade cronológica e capacidade. Desse ponto de vista, a teoria da estratificação por idade, descrita por Maria Siqueira (2001, p. 96-97), sustenta aplicações como estas, pois permite agrupar indivíduos de uma dada sociedade por idade e classe social. Um dos aspectos positivos dessa teoria é o de mostrar que existem variações significativas entre pessoas idosas dependendo de sua "coorte etária", sugerindo "a necessidade de maior ênfase na análise de fatores históricos e sociais do envelhecimento", a qual pode avançar com a inclusão de outros elementos diferenciadores como a raça, gênero e classe social, explorando a heterogeneidade implícita no processo de envelhecimento.

Por sua vez, dentre as várias consequências apontadas por Camarano e Pasinato (2004, p. 5) com relação ao uso da idade para a definição de idoso, estão as limitações impostas pela simples decisão de estabelecer idades-limite como um "poder prescritivo", criando expectativas e delimitando papéis e tarefas, independente das condições de existência de cada um. Como exemplo, as autoras citam o caso das aposentadorias compulsórias presentes no Brasil e em vários países do mundo. No entanto, ao desagregar em outras características possíveis o grupo "idoso", como sexo, estado conjugal, rendimentos, forma de inserção na família e outras, as autoras buscaram a heterogeneidade dessa categoria, quer em função das diferenciações na dinâmica demográfica, quer em função das condições socioeconômicas.

Levando em consideração todas essas questões, que procuram ampliar a categoria de idoso, estaremos preocupados em discutir a vida dos velhos no passado brasileiro, a partir de um estudo de caso, no qual os sujeitos analisados serão as pessoas livres de Campinas, em especial durante o período que a mesma saiu da condição de Freguesia vinculada à jurisdição da Vila de Jundiaí, passando pelo período de sua emancipação, ocorrido em 1797, até o ano de 1842, quando então ela veio a ser elevada à condição de cidade. Assim, cabe a pergunta: qual a idade limite que utilizaremos nesse estudo para indicar os velhos?

Isidro Dubert (2008, p. 88) afirma que, na Espanha, o Diccionario de Autoridades de 1726-1739 definia a velhice como a última etapa da vida, cujo extremo se chama decrepitude e começa aos sessenta anos, mas que uma ampla literatura médica do século XVIII e XIX entendia que ela poderia iniciar entre os 45 e 50 anos. Em um importante artigo de Peter Laslett (1995, p. 16) 
sobre a questão do envelhecimento, a idade de 60 anos é utilizada como parâmetro para indicar a mudança na expectativa de vida na Inglaterra entre o período de 1540-1990.

Por sua vez, em artigo inédito sobre velhos escravos José Flávio Motta (2008) propõe uma dis-' cussão inicial muito importante: "Seria o caso de trabalharmos com esse mesmo recorte etário para o século dezenove?", ou "seria o recorte etário dos 60 anos ou mais o mais adequado para identificar os 'escravos da terceira idade'?". Essa análise, que partiu de alguns documentos como o Primeiro Recenseamento Ceral do Império, de 1872, e a Lei dos Sexagenários, sinalizou para a adoção da idade de 60 anos como início da velhice. Não obstante, os estudos sobre a longevidade dos escravos apontaram para outra direção. Assim, o autor afirmou que:

entendemos que a idade de 60 anos é muito elevada para servir como limite inferior da categoria de "escravos idosos" com a qual trabalhamos. [...] Por fim, e mesmo correndo o risco de incorporar certa dose de arbitrariedade, as indicações selecionadas nortearam nossa opção pelo cômputo, como cativos idosos, daqueles com idades iguais ou superiores a 50 anos. Tal definição será utilizada, ademais, não apenas para a segunda metade do século XIX, mas para o Oitocentos como um todo (MOTTA, 2008, p. 5).

Por sua vez, a antropóloga Guita Debert (1999, p. 46), ao discutir a questão da homogeneidade e heterogeneidade na velhice, aponta para um artigo de Philippe Ariès (1983), no qual ele faz uma análise das mudanças ocorridas entre três gerações de pessoas, sendo que para as nascidas no século XIX a faixa etária correspondente à velhice seria iniciada, para as mulheres, entre 40 e 50 anos, e para os homens entre os 50 e 60 anos. Já Dora Celton (1993), em estudo sobre a população de Córdoba, dado a baixa expectativa de vida encontrada, cerca de 30 anos, considerou como população anciã aquele segmento etário entre 50 ou mais anos. Além disso, Hernán Otero (2013, p. 9) nos chama atenção para a finalidade dos levantamentos populacionais do século XIX, que em virtude do foco na questão tributária, davam maior atenção às pessoas com idade entre 15 e 50 anos, com um certo desdém pelas populações femininas e masculinas fora dessa faixa etária. No entanto, referindo-se ao primeiro censo argentino de 1869 , o autor declara que:

Em primeiro lugar, ratifica a definição de crianças como os indivíduos "de 1 a 14 anos inclusive" (Argentina, 1872: XXVIII), definição coerente com a empregada nos quadros estatísticos. Entretanto, mais interessante ainda, por sua novidade, foi a postulação dos $\mathbf{5 0}$ anos como limite final da idade adulta, umbral que, como temos visto, representava também uma continuação da tradição estatística colonial. (OTERO, 2013, p. 10, grifos nossos).

Considerando, portanto, as análises de Motta para a população escrava do Brasil no século XIX, as de Ariès para França do mesmo período, e os trabalhos de Celton e Otero, o conceito de idoso 
adotado neste ensaio e estabelecido a partir da faixa etária corresponderá a todos os indivíduos que foram identificados com 50 anos ou mais, devendo levar em consideração questões de gênero, de estado social ou classe e etinicidade, cujo objetivo é o de poder diferenciar os grupos de mulheres e homens dentro de uma mesma população, como a brasileira, por exemplo.

\section{Fontes, objetivos e metodologia aplicada}

O propósito deste trabalho consiste em analisar as principais características sócio demográficas da população livre e idosa de Campinas, a partir das informações encontradas nas Listas Nominativas de Habitantes, nos Registros Paroquiais, nos Inventários e Testamentos, proporcionando uma gama de dados quantitativos e qualitativos que permitirão entender o comportamento dos idosos dos séculos XVIII e XIX.

Tendo em mente a preocupação em desvincular o conceito de "velho" como alguém totalmente dependente de outros, sendo inclusive uma carga econômica para sua família e para a sociedade, nos valeremos de algumas ideias de David S. Reher (1997), que propõe estudar o papel econômico dos idosos, bem como seu peso na população total, não vinculando uma idade limite entre a produtividade e a inatividade para todos os tempos. Ao chamar nossa atenção para distinguirmos o tipo de dependência requerida pelos velhos frente às crianças, assim como para reconhecermos a heterogeneidade da experiência de envelhecimento entre homens e mulheres, o autor propõe uma análise mais detida nas diferenças, como pode ser exemplificada na situação de viuvez, pois as mulheres tendiam à demorar mais tempo para contrair as segundas núpcias em relação aos seus parceiros do sexo masculino.

\section{A população de Campinas}

A partir da última década do século XVIII, Campinas passou a ter um crescimento populacional cada vez maior. No entanto, cabe frisar que, em grande medida, isto se deveu a diversos fatores como a reorganização da Capitania de São Paulo a partir de 1765, a expansão da lavoura canavieira e a consequente procura por terras de melhor qualidade para o cultivo da cana-de- 
- açúcar, atraindo pessoas de condição social livre, dentre as quais muitas instalaram engenhos para o fabrico do açúcar com o uso intensivo da mão de obra escrava africana, favorecendo com isso a entrada maciça de cativos na região.

Tabela 1 - Distribuição da população total por condição social. Campinas: 1774, 1794, 1814 e 1829.

\begin{tabular}{|c|c|c|c|c|c|c|}
\hline \multirow{2}{*}{ Ano } & \multicolumn{6}{|c|}{ Condição Social } \\
\cline { 2 - 7 } & \multicolumn{2}{|c|}{ Livres } & \multicolumn{2}{c|}{ Escravos } & \multicolumn{2}{c|}{ Total } \\
\cline { 2 - 7 } & Números & $\%$ & Números & $\%$ & Números & $\%$ \\
\hline 1774 & 390 & 81,7 & 87 & 78,3 & 477 & 100 \\
\hline 1794 & 1.373 & 73,4 & 498 & 26,6 & 1.871 & 100 \\
\hline 1814 & 3.613 & 65,6 & 1.893 & 34,4 & 5.506 & 100 \\
\hline 1829 & 3.662 & 43,3 & 4.799 & 56,7 & 8.461 & 100 \\
\hline
\end{tabular}

Fonte: Listas Nominativas de Habitantes (Fundo Péter Eisenberg, Arquivo Edgard Leuenroth, Unicamp).

Como podemos notar por meio da Tabela 1, até 1814 a entrada de livres foi muito importante para o crescimento demográfico da vila campineira em termos absolutos. Por exemplo, dos 527 chefes de domicílio que declararam a naturalidade, apenas 67 eram nascidos em Campinas (TEIXEIRA, 2004, p. 114). Por outro lado, o aumento relativo da população cativa foi, paulatinamente, se tornando mais expressivo, a ponto desse grupo se tornar majoritário em 1829. Sobre este momento, Slenes (1998, p. 17) afirmou que "Açúcar e escravidão rapidamente tornaram-se praticamente "sinônimos" em Campinas e o crescimento da população cativa foi explosivo: em torno de $18 \%$ ao ano entre 1789 e 1801 , e $5 \%$ ao ano entre 1801 e $1829 "$.

Gráfico 1 - Pirâmide Etária da População Livre. Campinas: 1774.

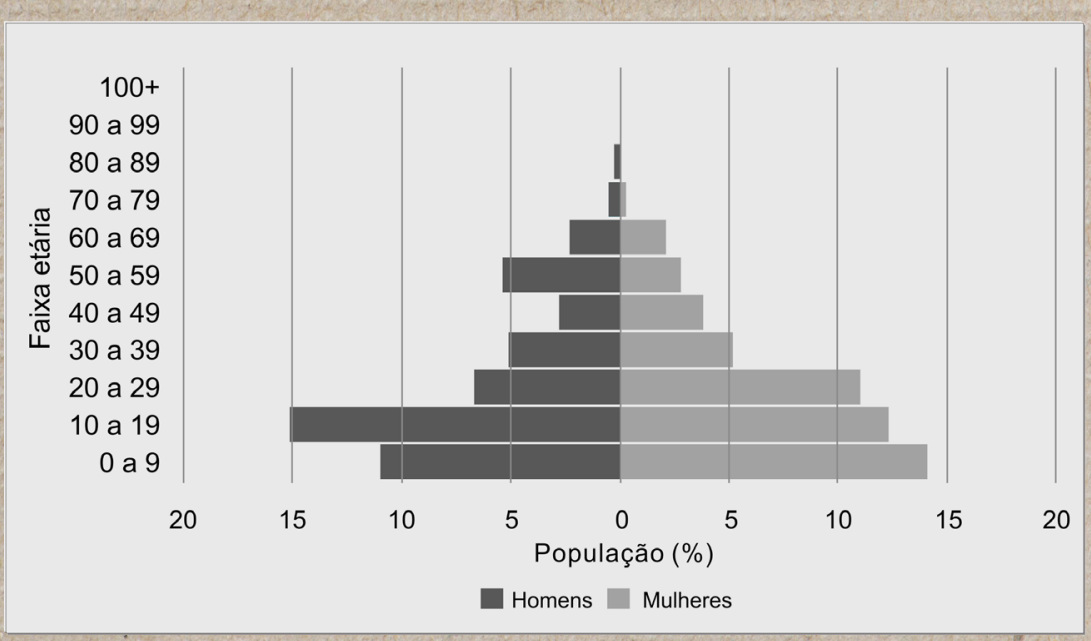

Fonte: Lista Nominativa de Habitantes (Fundo Peter Eisenberg, AEL, Unicamp).

Em 1774, conforme ilustra o Gráfico 1, havia em Campinas uma população predominantemente jovem, composta por casais com filhos menores e com alguns desníveis em determinadas faixas de idade, notadamente nà faixa entre 20 e 29 anos, em que a razão de sexo foi de 60,5, o que 
demonstra com clareza a emigração de homens nessas idades. Por outro lado, na faixa seguinte, isto é, entre 30 e 39 anos, a razão de sexo foi de 117,6 , com o predomínio dos homens, talvez por morte de mulheres nessa faixa de idade, o que poderia estar relacionado com os óbitos durante o parto. Já nas faixas caracterizadas pela velhice, encontramos $8,5 \%$ dos homens acima dos 50 anos, correspondendo a 33 pessoas, e $5,2 \%$ do total de mulheres, ou seja, apenas 20 .

Passados vinte anos, a configuração clássica de uma pirâmide de base larga que sinaliza para um forte crescimento vegetativo pode ser vista no Gráfico 2. As crianças com menos de 1.0 anos correspondiam a $35,8 \%$ da população total, filhos dos muitos casais que aparecem nas listas de habitantes, formando domicílios do tipo nuclear em sua grande maioria. Apesar de haver um maior número de nascidos do sexo masculino, esse predomínio não se manterá nas faixas seguintes, indicando que a mortalidade infantil entre os meninos deve ter sido maior que a das meninas. Aliás, nas faixas de 10-19 e de 20-29 anos, a presença de mulheres está bem marcada, indicando a chefia de muitos domicílios, como já assinalado em outros estudos (MARTINS, 1996; COSTA, 1997; TEIXEIRA, 2004). Essa tendência permaneceu durante as quatro primeiras décadas do século XIX. No entanto, cabe dizer que, a partir de 1794, se nota um maior desequilíbrio entre homens e mulheres na faixa de 10 a 19 anos. Enquanto observamos que a razão de sexo desse ano foi de 76 , a de 1814 foi de 92,5 (Gráfico 3) e atingiu, em 1829, a marca mínima de 67,7 (Gráfico 4), demonstrando a ausência de jovens rapazes, o que pode apontar para processos migratórios para áreas de fronteiras, ou mesmo o temor do alistamento para as guerras no sul (PERECALLI, 1986, pp. 63-72), conforme assinalado por Maria Luiza Marcílio (2000, p. 83) como fator para justificar uma razão de sexo tão baixa entre o ano de 1798 e 1836 em São Paulo. Para aqueles que passaram dos 50 anos de vida, houve uma ação inversa, com a redução do número de mulheres, elevando assim a razão de sexo para 127.

Gráfico 2-Pirâmide Etária da População Livre. Campinas: 1794.

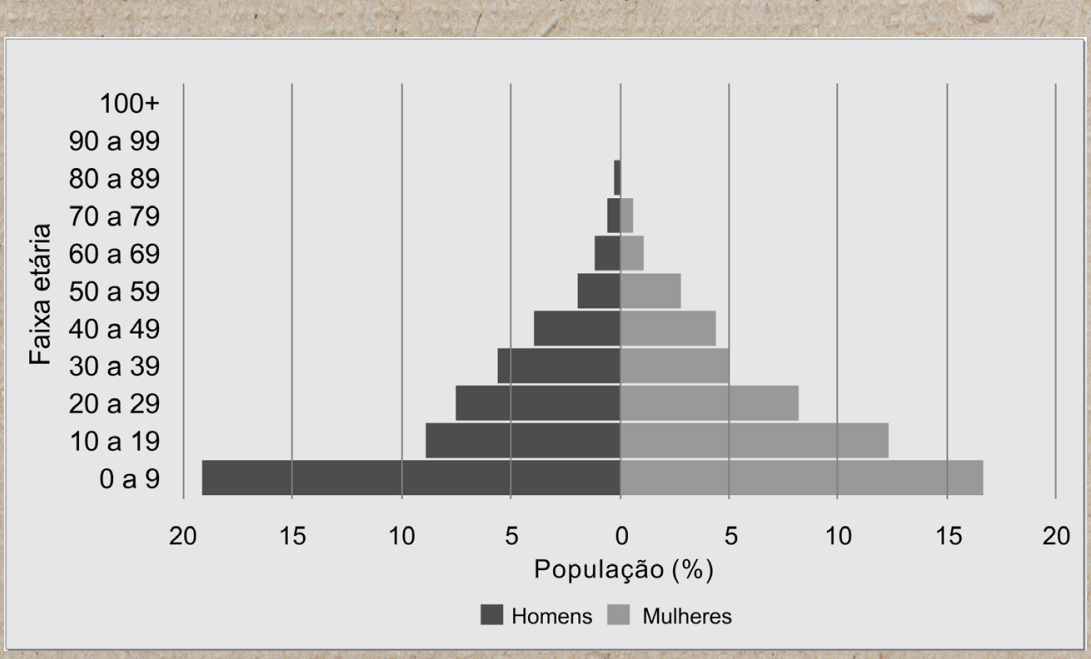

Fonte: Lista Nominativa de Habitantes (Fundo Peter Eisenberg, AEL, Unicamp). 
Em 1814, a população idosa ainda se manteve pequena em relação ao total da população, sendo que foram registradas apenas 102 mulheres com idades acima dos 50 anos, ou seja, apenas $3,4 \%$ do total, e 157 homens na mesma condição, isto é, 5,3\% do total masculino. A presença de septuagenários e outros mais velhos foram recorrentes ao longo dos anos estudados, porém a maior parte dos idosos se enquadrava entre os 50 e 60 anos de idade, sendo que nesse grupo estava abrigada a maioria dos velhos, chegando a representar $72 \%$ em 1829. Com 90 anos de idade e residindo no centro da vila, estava Escolástica Maria ${ }^{3}$, viúva que vivia como agregada de seu filho, Jorge Antonio de Moraes, de 35 anos, ambos naturais de Juqueri. Nos bairros rurais da vila campineira, viviam Joaquim Alvez, de 92 anos, branco, solteiro e que colheu para o seu gasto e de seus agregados, Vicente, de 82 anos, homem negro e viúvo, que também vivia ao lado de Joaquim, de 29 anos, solteiro e pardo 4 .

Gráfico 3 - Pirâmide Etária da População Livre.Campinas: 1814.

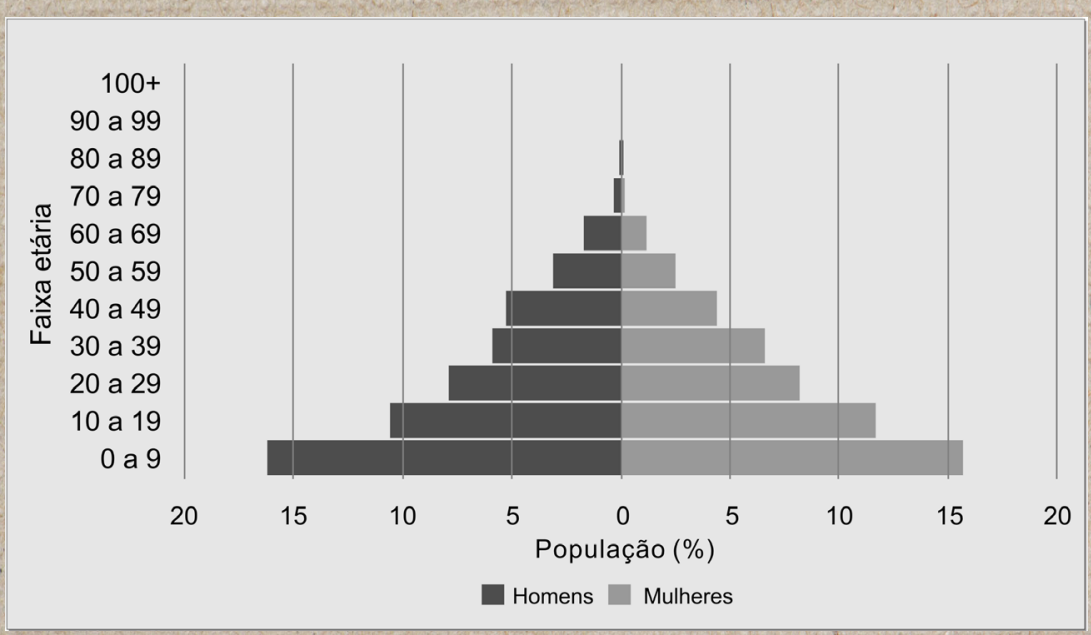

Fonte: Lista Nominativa de Habitantes (Fundo Peter Eisenberg, AEL, Unicamp).

Por sua vez, Salvador, de 94 anos, era casado com Maria, de apenas 41, ambos pardos e agregados de Duarte Lopes, um senhor de 57 anos, também casado, que vivia com suá mulher Maria Francisca, de 62 anos, ambos brancos e donos de cinco escravos 5 . E dentre os mais idosos, encontramos o centenário Felis da Costa, um alfaiate pardo, chefe de domicílio e que se disse casado, embora a mulher não estivesse arrolada na lista nominativa. Viera provavelmente do Rio de Janeiro, e vivia com o agregado Francisco, de apenas 10 anos de idade, além dele, Felis, com 108 anos $^{6}$.

3 Lista Nominativa de Habitantes, 1829, Cia 7, fogo 75 (Fundo Peter Eisenberg - AEL/Unicamp). 4 Lista Nominativa de Habitantes, 1829, Cia 4, fogo 63 (Fundo Peter Eisenberg - AEL/Unicamp). 5 Lista Nominativa de Habitantes, 1829, Cia 4, fogo 55 (Fundo Peter Eisenberg - AEL/Unicamp). 6 Lista Nominativa de Habitantes, 1829, Cia 1, fogo 88 (Fundo Peter Eisenberg - AEL/Unicamp). 


\section{História Econômica $\quad$ Dossiê
Demografia Históncá}

Gráfico 4 - Pirâmide Etária da População Livre. Campinas: 1829.

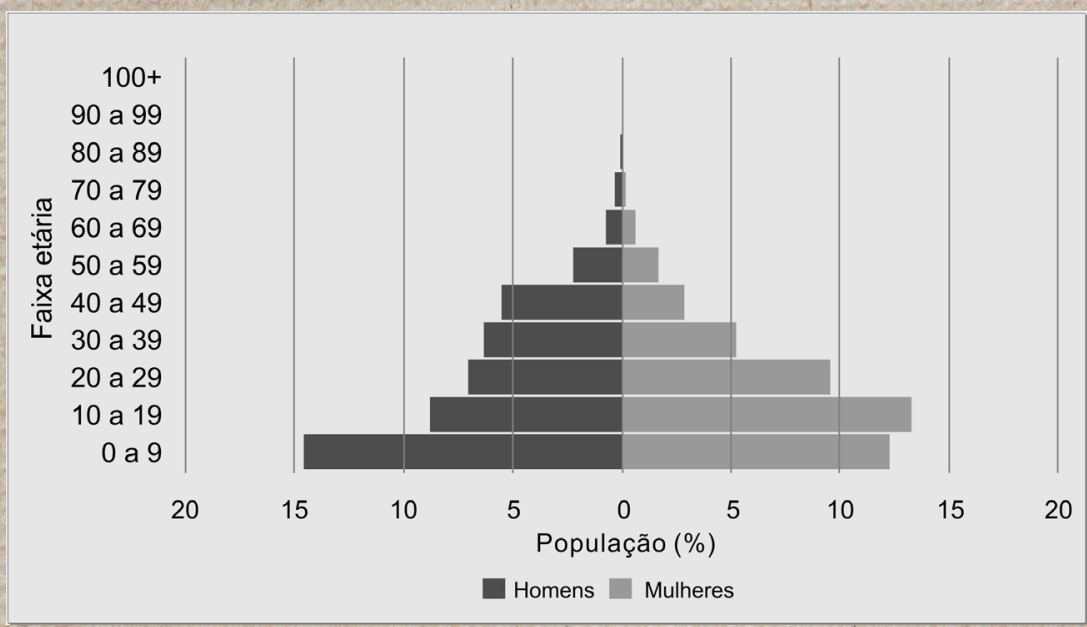

Fonte: Lista Nominativa de Habitantes (Fundo Peter Eisenberg, AEL, Unicamp).

Avaliando a presença de homens e mulheres nas faixas de 0 a 14 anos entre o período de 1774 e 1829 , notamos um equilíbrio entre os sexos, o que nos levou a descartar a hipótese de um crescimento diferenciado e a aceitar a possibilidade de emigração de homens da faixa etária dos adultos para outras localidades mais ao Oeste. Em 1794, a importância dos jovens cresceu significativamente, atingindo quase a metade $(49,2 \%)$ da população cadastrada, mas declinando nos anos subsequentes de tal

Gráfico 5 - Evolução dos Crupos Funcionais. . Campinas, 1774-1829.

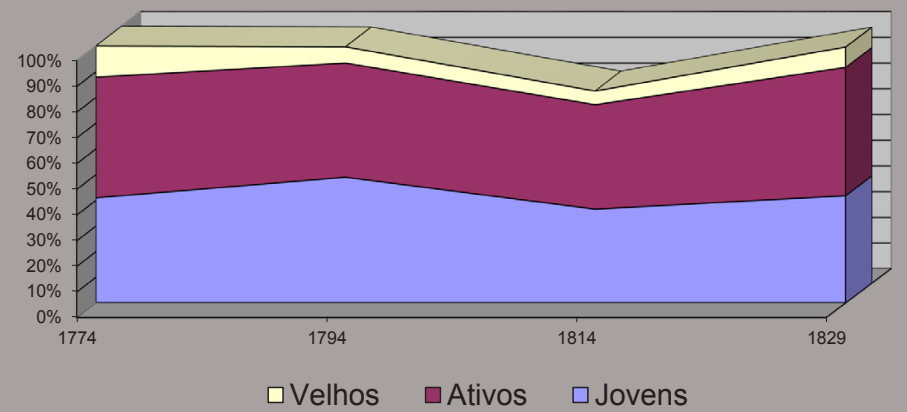

Fonte: Lista Nominativa de Habitantes (Fundo Peter Eisenberg, AEL, Unicamp).

* Os jovens foram classificados entre 0 e 14 anos, idade com que os homens já poderiam contrair matrimônio segundo as Constituições Primeiras do Arcebispado da Bahia de 1707. Para os adultos adotamos a idade de 15 aos 50 anos, por achar que, em virtude de uma baixa expectativa de vida naquele tempo, o período de 35 anos seria relativamente viável para a idade ativa de uma pessoa. Finalmente os velhos foram considerados acima de 50 anos, onde especialmente as mulheres acima dessa idade já estariam na fase da menopausa e, portanto, não mais contribuindo para o aumento populacional. forma que, em 1814, as crianças representavam $44,1 \%$ do total de habitantes, passando a $39,6 \%$ em $1829^{7}$. Sublinhe-se que essa diminuição na proporção de crianças pode estar atrelada ao movimento migratório de saída de casais em busca de novas oportunidades na frente pioneira aberta mais a Oeste, mas não afetou negativamente a evolução populacional no que se refere à geração de ćrianças, e, portanto, de pessoas das novas gerações. Ao que parece, o movimento migratório de saída de livres foi o responsável por manter o número da população estável até a década de 1830 , não aumentando seus efetivos (Cf. TElXEIRA, 2004, p. 99-102). Além disso, o predomínio de mulheres nessas faixas etárias pode estar relacionado ao número de mulheres chefes de domicílio, que era de aproximadamente $25 \%$ em 1829, como indica o Gráfico 4.

7 Deve-se salientar que, para o ano de 1814, não tivemos informação da idade para 575 pessoas do total de 3.613 cadastradas na Lista Nominativa de Habitantes desse ano e isso, talvez, justifique uma queda nos percentuais de jovens. 
Enfim, a partir da década de 1830, Campinas começou a passar por outro momento, que trouxe algumas mudanças que vieram a transformar a vila, como, por exemplo, o início da chegada de imigrantes estrangeiros, que pouco a pouco tomaram parte ativa nas atividades econômicas da cidade, seja no campo, enquanto lavradores meeiros dos cafezais que se multiplicaram, ou no comércio e indústria, que se expandiu, sobretudo, a partir de 1850. Tais fatores podem ter reforçado, ainda mais, o percentual de pessoas ativas entre a população campineira, que já era elevado em 1829, com uma participação de praticamente $50 \%$, conforme apresentado pelo Gráfico 5 .

Um estudo para uma vila da ilha açoriana de São Jorge (MADEIRA, RODRICUES \& MATOS, 1998) apresentou uma tendência semelhante à encontrada para Campinas: elevado percentual de jovens e ativos, com uma parcela menor de velhos. Além do mais, o Gráfico 5 ilustra a participação do contingente de idoso ao longo dos anos estudados, dando-nos a ideia de ser uma população pequena, e como veremos, com o predomínio de homens, uma tendência muito diversa daquela que conhecemos em nossos dias.

\section{Os idosos de Campinas}

Através de uma perspectiva demográfica, vamos passar a conhecer alguns aspectos relacionados à parcela da população idosa que viveu em Campinas a partir do ano de 1774. Sem dúvida, os atores que compuseram esse grupo foram muito diversos, e alguns deles, que nasceram e cresceram durante o processo de emancipação de Campinas, quando a mesma se tornou uma vila com destacada importância econômica e política, já haviam atingido a velhice. Para exemplificar, vamos citar a pessoa de Domingos, filho de Maria Barbosa do Rego e do tenente Domingos da Costa Machado, que foi batizado no dia 14 de julho de 1774 , sendo seu padrinho o Capitão Raimundo da Silva Prado. ${ }^{8}$ Percorrendo a trajetória de Domingos percebemos que o mesmo seguiu a carreira militar: assim, este filho de Campinas, aos 25 anos de idade, já havia se tornado um alferes, possivelmente para orgulho de seu pai, pois Domingos era o único filho homem de seu pai, além de ser o caçula. No entanto, antes de ver seu filho tornar-se um tenente, Domingos da Costa Machado, o pai, veio a falecer no dia 2 de fevereiro de 1808. Em 1820, Domingos, o filho, foi elevado ao posto de capitão, permanecendo nessa condição até 1826 , quando atingiu a posição de sargento mor. Finalmente, aos 60 anos de idade, Domingos da Costa Machado, o filho, atingiu o cargo máximo de major.

A história familiar dos Machado nos remete a pelo menos dois pontos. O primeiro, a presença do casal adulto representando uma parcela significativa da população com idade para gerar, traba-

8 Registros Paroquiais de Batismos de Campinas, Livro 1, Folha 2, 14 jul. 1774. (Arquivo da Cúria Metropolitana de Campinas). 
Ihar e poder acumular um capital "material" e "simbólico". O segundo está retratado pelo nascimento do filho, pois apesar do mesmo ter nascido e vivido mais de 60 anos, isso não o impede de representar a trajetória das crianças nascidas naquela época. Por estarem cercadas de condições que eram adversas ao bom desenvolvimento infantil, e que muitas vezes levavam à morte prematura de crianças - atestada claramente pelos elevados índices de mortalidade infantil -, pode-se entrever a possibilidade de muitas crianças terem chegado à terceira etapa da vida, ou seja, a velhice. A herança deixada por Domingos pai foi além do próprio nome dado a seu filho, concretizou-se também na escolha do padrinho de batismo, o Capitão Raimundo, que esteve presente em seu primeiro casamento com Dona Manoela de Camargo Penteado, em 1795.?

O velho tenente Domingos, antes de morrer, ainda teve a oportunidade de ver os netos Ignácio, Maria, Ana, Delfina e Querubina, todos frutos do matrimonio entre seu filho e Dona Manoela Camargo. O ciclo de vida familiar, como uma grande roda gigante, levava Domingos da Costa Machado a se recolher em boa idade com seus ancestrais, ao passo que o filho Domingos estava atingindo o topo desta grande roda da vida. Enfim, nas palavras de Valter Martins (1996, p. 164), "Esses exemplos são representativos, mas não são os únicos. [...] contribuem também para evidenciar que a acumulação e a melhoria das condições materiais de vida não era algo assim tão raro", não só entre os agricultores que ele estudou, como também nos grupos sociais. Nas palavras de Bacellar (1997, p. 127):

Toda família, no transcorrer de seu ciclo de vida, atua permanentemente no sentido de preservare reproduzir seu status social. Cada ato ou decisão tomados são, conscientemente ou não, um passo no contínuo movimento de luta pela sobrevivência e pela perpetuação de sua descendência.

Nas próximas páginas vamos apresentar informações de caráter demógráfico, portanto muito impessoal. No entanto, à medida que as análises nos permitirem, vamos procurar lançar algumas reflexões baseadas também em informações colhidas de documentos que nos aproximam desse lado pessoal da vida de cada indivíduo.

\section{A propósito de alguns números}

Desde a fundação da Freguesia de Campinas, em 1774, a presença de pessoas com mais de 50 anos foi notada, e a idade média calculada chegou próximo dos 60 anos. No entanto, com o

9 Registros Paroquiais de Casamentos de Campinas, livro 1, 19/05/1795. (Arquivo da Cúria Metropolitana de Campinas). 
crescimento populacional, a participação dessa população decresceu um pouco proporcionalmente ao conjunto populacional, e nesse sentido houve também uma ligeira queda na média de idade, porém não muito significativa a ponto de suspeitarmos de algum fenômeno que pudesse reduzir drasticamente essa população. Assim, a Tabela 2 procurou dar uma ideia do ta-' manho da população de idosos durante o processo de crescimento da vila campineira. Embora tenha ocorrido um aumento do número de idosos ao longo do tempo, a proporção dos mesmos diante do aumento populacional não ultrapassou os $13,6 \%$ de 1774 , e mesmo em 1829 , em que $10,4 \%$ das pessoas eram velhas, e como já apontamos, muitas com mais de setenta anos, a média de idade não chegou aos $60 \operatorname{anos}^{10}$. O indicador da Moda revelou a já assinalada preferência pelos números com terminações 0 e 5 (Cf. EISENBERG, 1989, p. 331; NOZOE \& COSTA, 1991, p. 275), de tal forma que, em 1794, foram registradas 30 pessoas com a idade de 50 anos, que se elevou para 60 pessoas em 1814, e atingiu 93 casos em 1829 , o que representou, neste último ano, quase $25 \%$ dos idosos.

Tabela 2 - Peso da População Idosa e Idade Média. Campinas, 1774, 1794, 1874, 1829.

\begin{tabular}{|c|c|c|c|c|c|c|c|}
\hline \multirow{2}{*}{ ANO } & População Total & População Idosa & \multirow{2}{*}{ \% Idosos } & \multirow{2}{*}{ Razão Sexo Idosos } & \multicolumn{3}{|c|}{ Idade dos Idosos } \\
\cline { 5 - 8 } & & & & & Média & Mediana & Moda \\
\hline 1774 & 390 & 53 & 13,6 & 165 & 59,7 & 58 & 52 \\
\hline 1794 & 1.373 & 116 & 8,4 & 127 & 59,8 & 58 & 57 \\
\hline 1814 & $3.613^{*}$ & 261 & 8,6 & 154 & 57,7 & 56 & 50 \\
\hline 1829 & $3.662^{* *}$ & 379 & 10,4 & 134 & 58,3 & 56 \\
\hline
\end{tabular}

Fonte: Lista Nominativa de Habitantes (Fundo Peter Eisenberg, AEL, Unicamp).

* Na lista de 1814 não consta idade para 575 pessoas, e o cálculo da porcentagem de idosos considerou esse sub-registro, sendo válidos, portanto 3.038 habitantes.

** Na lista de 1829 não consta a idade para 17 pessoas, e da mesma forma o cálculo da porcentagem de idosos considerou o sub-registro, sendo válidos 3.645 habitantes.

Pensar a diferença de sexo e estado conjugal nos levou a compor quatro tabelas para conhecer como foi o comportamento dessa população nos anos de 1774, 1794, 1814 e 1829. Na Tabela 3, os dados de 1774 indicam que os 53 velhos que viviam em Campinas representavam as famílias fundadoras da Freguesia, daí a quantidade maior de homens casados, com 50 ou mais anos de idade, como ilustra a imagem do fundador de Campinas Francisco Barreto Leme que, nascido em Guaratinguetá, recebeu carta do Morgado de Mateus para realizar essa tarefa aos 65 anos de idade, acompanhado de sua mulher Dona Roza Maria, de 62 anos, juntamente com mais quatro filhos, sendo um destes Bernardo Guedes Barreto que, na ocasião; aos 23 anos de idade, já era casado com Maria Antonia e com ela tivera dois filhos. Este mesmo Bernardo foi um dos signatários da petição

10 Em relação ao ano de 1814, os dados da Lista Nominativa deixam um número expressivo de pessoas fora das possibilidades de análise em virtude da falta da idade. Para contornar isso, buscamos no Mapa Ceral de Habitantes de Campinas essa informação, e o resultado foi o seguinte: a população total somou 3.671 habitantes, sendo considerados idosos $10,6 \%$, ou seja, 390 pessoas. Tal resultado aproxima a proporção de idosos de 1814 à de 1829, indicada na Tabela 2, corrigindo, em parte, o efeito do sub-registro assinalado. 


\section{História Econômicag $\quad$ Dossiê
Demografia Histónica}

para ereção da vila, e posteriormente foi eleito vereador para a Câmara de 1799 a 1804, segundo Jolumá Brito (1956, p. 132). Em 1815, Bernardo Cuedes Barreto era um dos senhores de engenho de Campinas, contando com o trabalho de 32 escravos em sua propriedade, e mais 15 agregados, dos quais alguns eram donos de outros 12 escravos $^{11}$. Além disso, em 1818, quando foram cadastradas as terras em Campinas pelo poder público, o mesmo possuía uma sesmaria no Taquaral equivalente a 450 alqueires, sendo que o número de seus escravos havia sido elevado para $39 .{ }^{12}$

Tabela 3 - Faixa etária dos habitantes idosos pelo estado conjugal e sexo.

Campinas, 1774

\begin{tabular}{|c|c|c|c|c|c|c|c|c|c|}
\hline \multirow{2}{*}{ Faixa Estaria } & \multicolumn{2}{|c|}{ Casados } & \multicolumn{2}{|c|}{ Viúvos } & \multicolumn{2}{|c|}{ Solteiros } & \multicolumn{2}{|c|}{ Indefinido } & \multirow{2}{*}{ Total } \\
\hline & Homens & Mulheres & Homens & Mulheres & Homens & Mulheres & Homens & Mulheres & \\
\hline $50-59$ & 17 & 8 & 2 & 1 & & 2 & 2 & 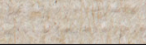 & 32 \\
\hline $60-69$ & 8 & 3 & & 4 & & & 1 & 1 & 17 \\
\hline $70-79$ & 2 & & & 1 & & & & & 3 \\
\hline $80+$ & & & 1 & & & & & & 1 \\
\hline Total & 27 & 11 & 3 & 6 & 0 & 2 & 3. & 1 & 53 \\
\hline \multicolumn{10}{|c|}{ Campinas, 1794} \\
\hline \multirow{2}{*}{ Faixa Estaria } & \multicolumn{2}{|c|}{ Casados } & \multicolumn{2}{|c|}{ Viúvos } & \multicolumn{2}{|c|}{ Solteiros } & \multicolumn{2}{|c|}{ Indefinido } & \multirow{2}{*}{ Total } \\
\hline & Homens & Mulheres & Homens & Mulheres & Homens & Mulheres & Homens & Mulheres & \\
\hline $50-59$ & 29 & +14 & 1 & 3 & 1 & & 2 & .9 & 59 \\
\hline $60-69$ & 12 & 9 & 1 & 2 & 1 & & 3 & 2 & 30 \\
\hline $70-79$ & 7 & .7 .7 & 1 & 4 & & 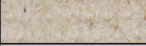 & $1:-3$ & 5 & 19 \\
\hline $80+$ & 4 & & & 1 & & & 2 & 1 & 8 \\
\hline Total & 52 & 24 & 3 & 10 & 2 & 0 & 8 & 17 & 116 \\
\hline \multicolumn{10}{|c|}{ Campinas, 1814} \\
\hline \multirow{2}{*}{ Faixa Estaria } & \multicolumn{2}{|c|}{ Casados } & \multicolumn{2}{|c|}{ Viúvos } & \multicolumn{2}{|c|}{ Solteiros } & \multicolumn{2}{|c|}{ Indefinido } & \multirow{2}{*}{ Total } \\
\hline & Homens & Mulheres & Homens & Mulheres & Homens & Mulheres & Homens & Mulheres & \\
\hline $50-59$ & 90 & 43 & 17 & 3 & 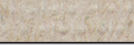 & 1 & 6 & 15 & 158 \\
\hline $60-69$ & 43 & 12 & & 4 & 2 & 1 & 5 & 15 & 82 \\
\hline $70-79$ & 7 & 1 & & +2 & se & + & 2 & 4 & 14 \\
\hline $80+$ & 2 & 2 & & & & & & 1 & 5 \\
\hline Total & 142 & 58 & 0 & 7 & 2 & $1 \quad 2$ & 13 & 35 & 259 \\
\hline \multicolumn{10}{|c|}{ Campinas, 1829} \\
\hline \multirow{2}{*}{ Faixa Estaria } & \multicolumn{2}{|c|}{ Casados } & \multicolumn{2}{|c|}{ Viúvos } & \multicolumn{2}{|c|}{ Solteiros } & \multicolumn{2}{|c|}{ Indefinido } & Total \\
\hline & Homens & Mulheres & Homens & Mulheres & Homens & Mulheres & Homens & Mulheres & \\
\hline $50-59$ & 107 & 47 & 9 & 34 & 10 & 15 & . & & 222 \\
\hline $60-69$ & 47 & 14 & 12 & 28 & 6 & 3 & & & 110 \\
\hline $70-79$ & 12 & 3 & 1 & 10 & 2 & 1 & 1 & 4 & 30 \\
\hline $80+$ & 5 & 1 & 3 & 6 & 1 & & & & 16 \\
\hline Total & 171 & 65 & 25 & 78 & 19 & 19 & 1 & 0 & 378 \\
\hline
\end{tabular}

Fonte: Lista Nominativa de Habitantes (Fundo Peter Eisenberg, AEL, Unicamp).

11 Lista Nominativa de Habitantes, Ano 1814, Cia 2. a, fogo 10 (Fundo Peter Eisenberg - AEL/Unicamp). 12 Inventário dos Bens Rústicos de Campinas, 1818 (Arquivo do Estado de São Paulo). 
Após a morte de Bernardo Cuedes Barreto, a sesmaria foi repartida entre seus filhos, sendo que Vicente Guedes Barreto, que havia se casado com dona Matilde Maria de Souza, de Mogi-Mirim, tornou-se um dos pródigos herdeiros do pai. Deste consórcio nasceu José Guedes de Souza, em 1830, que veio a se tornar fazendeiro de café em Mogi-Mirim e Santa Rita do Passa-Quatro, proprietário de terras no Estado do Paraná, capitalista em São Paulo, e um dos fundadores da Companhia Mogiana de Estradas de Ferro, na qual, por alguns anos, foi membro da diretoria. Como Barão de Pirapitingui, título recebido em 7 de maio de 1887, Guedes de Souza por duas vezes hospedou em sua residência, em Mogi-Mirim, Sua Majestade Imperial Dom Pedro II ${ }^{13}$.

Além de idosos casados, havia também viúvos, não muitos, como Mariana Barboza, de 72 anos, que vivia ao lado de seus 9 filhos, sendo dois deles casados. Suzana de Gusmão era outra viúva, de 65 anos, que vivia ao lado de apenas dois filhos, sendo um destes Maria, de 50 anos de idade e cega. Bárbara Correia, de 62 anos, era outra viúva, mas que vivia com seu filho João Correia do Prado, de apenas 24 anos $^{14}$.

A Tabela 3 também nos apresenta as informações para o ano de 1794, e nela podemos notar a importância dos casais de idosos, como em 1774. Há uma pequena presença de viúvos e muito ínfima de solteiros. Vale destacar que a maior parte dos idosos tinha entre 50 e 60 anos, não obstante encontramos alguns que superavam essa faixa de idade, como fora o caso de Antonio, que aos 90 anos era um dos agregados de Bernardo Cuedes Barreto ${ }^{15}$. Quanto à significativa incidência de casos indefinidos, podemos atribuir que, para muitas pessoas, o estado conjugal não declarado esteve atrelado à condição social de agregado, como no caso de Maria, 53 anos, e Ana, 50 anos, ambas agregadas de Joaquim Oliveira ${ }^{16}$.

Em relação ao ano de 1814, podemos dizer que a grande quantidade de casos indefinidos em relação ao estado conjugal, bem como ao sub-registro em relação à idade, mencionado anteriormente na Tabela 2 , sem dúvida são os responsáveis por não identificarmós os viúvos e solteiros que viviam na vila de Campinas nessa época, como na situação de Tereza Machada, de 70 anos que cuidava de um menino de 12 anos, agregado a ela, mas cujos problemas relativos à conservação dos registros impedem a certeza quanto ao seu estado conjugal ${ }^{17}$. Não obstante, eram os casados o maior grupo de idosos, sobretudo até os 60 anos de idade, pois acima dessa faixa etária a morte por parte de um dos cônjuges se tornava imperiosa, como demonstrado pelos dados dos anos de 1814 e 1829 da Tabela 3, forçando muitos destes a vive-

13 Decreto em 07/05/1887 (Cf. Fundo Jolumá Brito, Centro de Memória - Unicamp, Série Personagens. Dados biográficos. Barões diversos, p. 285).

14 Lista Nominativa de Habitantes, Ano 1774, Fogo 27, 37 e 2 (Fundo Peter Eisenberg, AEL, Unicamp).

15 Lista Nominativa de Habitantes, Ano 1794, Fogo 31 (Fundo Peter Eisenberg, AEL, Unicamp).

16 Lista Nominativa de Habitantes, Ano 1794, Fogo 12 (Fundo Peter Eisenberg, AEL, Unicamp).

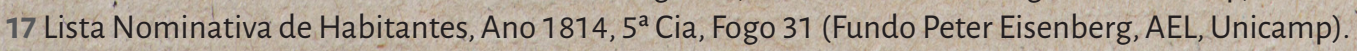




\section{História Econômicag $\quad$ Dossiê
Demografia Histónica}

rem solitariamente por ocasião da morte de um dos cônjuges. Marcílio (1986, p. 199) assevera que o momento da morte de uma pessoa adulta, sobretudo quando esta ocupava posição de liderança no interior do domicílio, "criava rupturas e problemas para a sobrevivência do grupo doméstico. Ela poderia romper o equilíbrio da família, causar danos difíceis de serem contornados, levar à miséria ou ao desamparo os sobreviventes".

A compilação das informações para 1829, conforme a Tabela 3, é fruto das condições ideais para a exploração de um documento dessa natureza, e assim nos aproxima, com maior nitidez, da população de velhos existente naquele ano. Apesar de continuar a haver um predomínio de homens e mulheres casados/as, há um aumento significativo dos viúvos e solteiros. Em relação às mulheres viúvas e solteiras, podemos dizer que este aumento está intimamente vinculado à chefia feminina da família ou domicílio, e que o crescimento econômico da vila permitiu a sobrevivência de um grande número de mulheres nestas situações (TEIXEIRA, 2004). A viúva Clara Maria de Jesus, de 58 anos, e Ana Maria do Prado, de 60 anos, que viviam de suas agências, são exemplos de algumas dessas mulheres que, apesar da idade, eram as responsáveis por suas casas $^{18}$.

Tabela 4 - Faixa etária dos habitantes idosos pela cor e sexo. Campinas, 1874

\begin{tabular}{|c|c|c|c|c|c|c|c|}
\hline \multirow{2}{*}{ Faixa Estaria } & \multicolumn{2}{|c|}{ Brancos } & \multicolumn{2}{|c|}{ Pardos } & \multicolumn{2}{|c|}{ Negros } & \multirow{2}{*}{ Total } \\
\hline & Homens & Mulheres & Homens & Mulheres & Homens & Mulheres & \\
\hline $50-59$ & 59 & 30 & 36 & 32 & & 26 & 157 \\
\hline $60-69$ & 30 & 14 & 20 & 18 & & & 82 \\
\hline $70-79$ & 7 & 3 & 2 & 2 & & 8 & 1.4 \\
\hline $80+$ & & 2 & 2 & 1 & & & 5 \\
\hline Total & 96 & 49 & 60 & 53 & 0 & 0 & 258 \\
\hline \multicolumn{8}{|c|}{ Campinas, 1829} \\
\hline \multirow{2}{*}{ Faixa Estaria } & \multicolumn{2}{|c|}{ Brancos } & \multicolumn{2}{|c|}{ Pardos } & \multicolumn{2}{|c|}{ Negros } & \multirow{2}{*}{ Total } \\
\hline & Homens & Mulheres & Homens & Mulheres & Homens & Mulheres & \\
\hline $50-59$ & 83 & 63 & 42 & 30 & 1. & 3 & 222 \\
\hline $60-69$ & 58 & 36 & 8 & 8 & & 1 & 111 \\
\hline $70-79$ & 11 & 13 & 4 & 1 & 1 & se & 30 \\
\hline $80+$ & 4 & 5 & 4 & 2 & 1 & & 16 \\
\hline Total & 156 & 117 & 58 & 41 & 3 & 4 & 379 \\
\hline
\end{tabular}

Fonte: Lista Nominativa de Habitantes (Fundo Peter Eisenberg, AEL, Unicamp).

Quanto à cor declarada nas Listas Nominativas, vamos encontrá-las apenas para os anos de 1814 e 1829, sendo na Tabela 4 expostos os dados que demonstram o predomínio dos que eram brancos. Muitos destes eram filhos daquela geração que fundou Campinas, como Domingos da Costa Machado e Bernardo Cuedes Barreto, já citados, não obstante a presença de homens e mulheres

18 Lista Nominativa de Habitantes, Ano $1829,7^{\mathrm{a}}$ Cia, Fogo 35 e 47 (Fundo Peter Eisenberg, AEL, Unicamp). 
classificados como pardos surja com uma expressiva quantidade. Embora a presença de negros possa ser constatada desde o princípio do povoamento de Campinas, em virtude da existência de africanos escravizados que trabalhavam para muitos senhores, o aparecimento de negros livres, sobretudo acima dos 50 anos, vai ocorrer pela primeira vez apenas no ano de 1829.

Exemplo de casal idoso que vivia sem o auxílio aparente de filhos ou demais parentes é retratado por Ignacio Pereira da Silva, um agricultor, natural de Curitiba, que aos 88 anos era casado com Catarina Maria, de 57 anos, ambos pardos e vivendo da roça ${ }^{19}$. Roque de Miranda era outro pardo, nascido em São Roque, domiciliado, em 1829, em Campinas, onde vivia de seus jornais ao lado de sua mulher, a jovem Maria Luiza de apenas 22 anos, também parda ${ }^{20}$. Já Manoel Barbosa, um dos poucos negros livres e chefe de domicílio, vivia ao lado de sua mulher, Francisca de Brito, ela com 45 anos e natural de Atibaia. Manoel Barbosa, que nascera em Jundiaí, contava com 51 anos no ano de 1829 , e vivia da renda de seu trabalho como jornaleiro ${ }^{21}$. Mas foi outro Manoel que nos chamou a atenção pela idade de 70 anos, o qual era negro, solteiro, e vivia na condição de agregado no engenho de Ana Baptista, viúva de 66 anos, que tocava seu engenho com 18 escravos, estando acompanhada por seu filho Joaquim, de 35 anos, casado com Ana Teolinda, de apenas $17.22 \mathrm{~A}$ possibilidade para fazermos conjecturas sobre a vida desses idosos são muitas, mas o retrato que nos é mostrado pela lista nominativa nos basta para percebermos o quanto era difícil para ex-cativos, especialmente os mais velhos, manterem sua sobrevivência. Apesar da modesta produção de 400 arrobas de açúcar do engenho de dona Ana Baptista, suas condições de envelhecimento foram impactadas pela sua condição social, que a colocava no topo da pirâmide social, em nítida oposição ao agregado Manoel. A caracterização dada ao sujeito agregado, por Eni de Mesquita (1977, p. 42), é "o fato de não possuírem nem uma pequena porção de terra ou casa própria, tendo, portanto, que se ajustar aos proprietários das áreas rurais ou urbanas, dentro dos mais diferentes tipos de relações". Essa definição não omite a existência de pessoas agregadas em condições socioeconômicas diferentes, como as situações em que encontramos mães, irmãos, filhos, sobrinhos ou netos do casal-chefe na condição de agregados, mas simplesmente aponta para a maior parte dos casos, em que eram solteiros e viúvos, com idade bem avançada, ou ainda crianças.

Como já vimos pela Tabela 1, a presença escrava foi aumentando na medida em que o século XIX foi avançando, e no ano de 1829 a população cativa superou a livre em números absolutos. Diante disso, qual teria sido a participação da população de idosos enquanto proprietários de escravos? Para responder a essa questão, estudamos as Listas Nominativas de 1794, 1814 e

19 Lista Nominativa de Habitantes, Ano $1814,5^{2}$ Cia, Fogo 50 (Fundo Peter Eisenberg, AEL, Unicamp). 20 Lista Nominativa de Habitantes, Ano 1829, $1^{\text {a }}$ Cia, Fogo 100 (Fundo Peter Eisenberg, AEL, Unicamp). 21 Lista Nominativa de Habitantes, Ano 1829, $7^{\mathrm{a}} \mathrm{Cia}$, Fogo 33 (Fundo Peter Eisenberg, AEL, Unicamp).

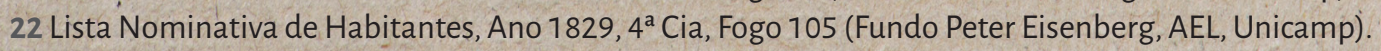


1829. O primeiro ponto a ser destacado é que o percentual de proprietários idosos sofreu uma variação de $35,7 \%$ em 1794 , para $30,4 \%$ em 1814 e atingiu a marca de $42 \%$ em 1829 . Outro aspecto para o qual chamamos a atenção do leitor é de que a maior concentração de escravos estava nas mãos de poucos senhores idosos, de modo que em 1794, estes eram responsáveis por $41 \%$ do total de escravos (498); em 1814; os velhos senhores eram proprietários de $37 \%$ da escravaria da Vila de Campinas (1.893) e, em 1829 , eles possuíam $43 \%$ dos cativos, de um total de 4.799. Mais significativa ainda é a concentração da riqueza na forma de escravos, pois no ano de 1794 oito idosos eram donos de 148 cativos, o que correspondeu a $71,9 \%$ da posse escrava dentre os escravistas com mais de 50 anos. Em 1814, essa concentração se fez ainda maior, quando apenas 14 idosos detinham a posse de pouco mais de $81 \%$ dos cativos pertencentes ao grupo dos velhos, proporção que não parou de crescer; enquanto, em 1829,48 senhores de escravos com mais de 50 anos possuíam $89 \%$ da escravaria desse seguimento social.

Essa pequena fração de idosos correspondia a senhores de engenho, proprietários de mais de 10 escravos, alguns com várias dezenas de cativos, como no caso de dona Ana Maria Ferras, viúva de 53 anos, que em 1829 contava com o trabalho de 70 escravos, além de 13 agregados, produzindo 2.400 arrobas de açúcar por ano. Ou ainda como exemplifica a condição de Francisco de Paula Camargo, casado aos 55 anos, e que era um senhor de engenho que produzia 1.500 arrobas de açúcar com o emprego de 59 escravos $^{23}$. Os resultados apresentados concordam com a assertiva de Peter Eisenberg (1989, p. 354), ao dizer que "Os chefes de fogo mais velhos nesses dois anos [1809-29] eram os donos de engenhos, seguidos pelos agricultores de alimentos e os prestadores de serviços".

Havia mulheres que se tornaram proprietárias de escravos, mas a maior parte delas era composta por viúvas. Isso é interessante de se notar a partir do momento que estudamos a posse de cativos pela faixa etária e sexo. Em relação aos homens, por exemplo, no ano de 1829 eram proprietários de escravos 89 pessoas, dos quais 49 (43\%) tinham entre 50 e 59 anos de idade. Por sua vez, as mulheres que aparecem em maior número.como senhoras de escravos estão entre 60 e 69 anos, e nesse mesmo ano de 1829 foram arroladas 15 mulheres nessa faixa etária, das 24 que teriam ao menos um escravo. Isso indica que muitas dessas mulheres eram provenientes de famílias abastadas, parte da elite local e que desfrutavam da herança, geralmente deixada por seus pais e/ou maridos, como bem demonstrou Carlos Bacellar (1997) ao estudar as famílias de elite do Oeste paulista.

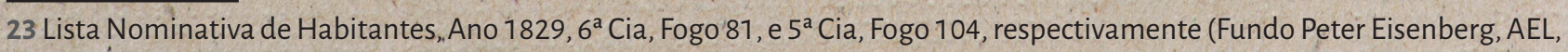
Unicamp). 
Por fim, outro aspecto a ser examinado é o estado matrimonial dos viúvos. A Tabela 5 indica que, de todos os casamentos realizados em Campinas ao longo de mais de 70 anos, apenas 3 tiveram como noivos e noivas pessoas enviuvadas. Sem dúvida, os casamentos eram preferencialmente realizados entre celibatários ( $90,5 \%$ dos casos), fato também atestado pelo estudo de Elvira Mari Kubo $(1974$, p. 83) para Curitiba, onde os casamentos entre celibatários realizados no decorrer do período de 1801-1850 corresponderam a 87,9\% dos noivos, sendo 7,1\% de "recasamentos" entre viúvos e noivas celibatárias. A viuvez para os homens era resolvida mais facilmente, pois dos casamentos em que havia ao menos uma pessoa viúva, 127 delas eram constituídas por homens nessa condição $(8,2 \%)$. Não obstante, as mulheres enviuvadas também preferiam casar-se com homens solteiros.

Tabela 5 - Estado matrimonial dos cônjuges por sexo. Campinas, 1774-1850.

\begin{tabular}{|c|c|c|c|}
\hline \multirow{2}{*}{ Mulheres } & \multicolumn{3}{|c|}{ Homens } \\
\cline { 2 - 4 } & Celibatário & Viúvo & Total \\
\hline Celibatária & 1.416 & 127 & 1.543 \\
\hline Viúva & 18 & 3 & 21 \\
\hline Total & 1.434 & $\mathbf{1 3 0}$ & 1.564 \\
\hline
\end{tabular}

Fonte: Registros Paroquiais de Casamentos de Campinas (Arquivo da Cúria Metropolitana de Campinas).

Assim, casar novamente era uma alternativa, mesmo para senhoras idosas como Dona Joanna Maria de Deos que, não se importando com sua avançada idade, casou-se com um homem 24 anos mais jovem, tornando-o um senhor de engenho. Vejamos o que ela disse em seu testamento:

Declaro que me rezolvo a contrahir outra ves o estado de Matrimonio com Joze Correia de Camargo y sendo eu já de idade sesagenaria e havendo netos filhos dos meos filhos [...] pesoa que bem administrou o Engenho e lavoura [sic] Contratei com dito meo marido nesta consideração Recebi como administrador e feitor [...] sic com o qual salario e trabalho se tem acresentado muito aproveitado os bens do meu cazal. nos quais ele dito meu marido não tem Comunicão algua Cujo contrato fis com elle antes do consorcio. Declaro que da minha terça de que tenho somente [sic] instituo por meu herdeiro dela ao dito meu marido Joze Correia de Camargo. [...] declaro que a mesma terça que dou ao dito meu marido já lhe doei antes de nosso consorcio e por isso agora confirmo a mesma doação. Sem que de tal doação exista outro titulo anterior ao casamento [...] (Testamento, $1838,7^{\circ}$ Of., Cx. $82, n^{\circ} 1947$, Tribunal de ]ustiça da Comarca de Campinas, Centro de Memória'-Unicamp) ${ }^{24}$.

Enfim, a "compra" de um marido poderia ser a solução de alguns problemas para aquelas muIheres que haviam deixado de șer pretendentes naturais, em função da idade, por exemplo. De

24 Outras informações na Lista Nominativa de Habitantes, Ano $1829,3 .{ }^{a}$ Cia, fogo 90. (Fundo Peter Eisenberg-AEL/Unicamp). 
acordo com Samara (1993, p.44), parece que fatores considerados relevantes para a escolha de um parceiro na época, como a riqueza e a origem, foram deixados de lado nesse caso, prevalecendo apenas o desejo da mulher.

O inverso também acontecia com homens que, em idade avançada e viúvos, queriam se casar. Fato semelhante sucedeu a José Correa Marques, pai de cinco filhos, sendo o caçula de 20 anos. Segundo uma testemunha, o mesmo Ihe dissera que, temendo "quebrar os preceitos de mandamento", preferiu casar-se, e assim fez. Ana Cardoza, a mulher escolhida, era uma jovem "mestiça mizeravel", como ela mesma se identificou. O casamento durou pouco mais de um ano, pois o velho veio a falecer, trazendo grandes transtornos para a jovem madrasta, pois os filhos herdeiros tentaram impedi-la de receber seu quinhão após a partilha dos bens, e para isso contrataram diversos advogados, sendo um deles o Dr. José Arouche de Toledo, da cidade de São Paulo. A principal alegação para impedir a partilha dos bens com a madrasta foi a seguinte:

[...] Por que o Pay dos Embargantes quando se cazou com a Embargada ja se achava doente de hidropezia, e da mesma molestia morreo, e com a Embargada não teve ajuntamento carnal para poder comonicarlhe a metade de sua meação, que por Direito do Reino lhe tocava cazo se confirmase o matrimonio [...] Por que a mesma Embargada tanto reconhece esta asserção que muitas vezes insitou a hum dos Embargantes a que se cazase com ella, por que com o Pay dos Embargantes não tinha confirmado o matrimonio, [...] se acha, pois que em hum anno que viverão de portas adentro não tiverão filho sendo a Embargada mossa, e bem disposta. [...] Por que conforme as leis do Reino que para marido, e mulher serem meeiros, e comunicar os bens de hum ao outro não só precizão cazar-se em face de Igreja, mas tão bem terem ajuntamento carnal, e não havendo este como não houve não deve a Embargada levantar ameação que se the fes neste inventario [...] (Inventário, 1798, 1. ${ }^{\circ}$ Of., CX. 1, nº 14, p. 29-84, Tribunal de ]ustiça da Comarca de Campinas, Centro de Memória - Unicamp).

Após a alegação de impotência, prevista como um dos impedimentos ao matrimônio sacramentado pela Igreja (Cf. SILVA, 1998, p.266-267), o processo continuou, eà defesa de Ana Cardoza, seguiram as testemunhas de ambas as partes envolvidas. Os filhos insistiam no fato de que a madrasta era mulher robusta e sadia, e como não havia sido "prenhada" no casamento, possivelmente não houvera "cópula carnal". A armação dos enteados não resistiu às provas, e Anna Cardoza levou o que era de direito para sua nova casa, pois, após o falecimento do marido, a jovem viúva casara-se com Manuel Fernandes.

Lana Lage (1987, p. 22) comenta que, por ser o casamento "uma instituição básica para a transmissão do patrimônio", era essencial que houvesse "igualdade social entre os noivos". Essa igualdade de que trata a autora referia-se aos aspectos de raça, religião e posição social, ele- 
mentos fundamentais à manutenção das ordens sociais. Nos casos dos viúvos que mencionamos acima, a preocupação de se casar com gente de sua "iguala" foi desprezada, e a diferença de idade surgiu como o primeiro indicador desse fato.

\section{Considerações finais}

Pelo exposto, viver e envelhecer em Campinas são processos que puderam ser reconstituídos a partir de histórias de vida recolhidas dos vários documentos ainda existentes sobre aquele período, assim como através da história de pessoas que eram velhas quando chegaram à vila campineira, ou ainda daqueles que nasceram naquela terra, cresceram, casaram, tiveram fiIhos e netos, e finalmente morreram.

No entanto, ao fazer um exame dentro de uma perspectiva demográfica, e transformando essas informações em elementos para uma análise da velhice no passado paulista, chegamos à conclusão que os homens tiveram mais anos de vida do que as mulheres depois dos 50 anos de idade, motivo pelo qual a razão de sexo durante o estudo foi mais elevada, indicando um predomínio do grupo de homens idosos, também presente como um fenômeno comum ao passado paulista, conforme atestado por Marcílio (2000, p. 82).

Assim, se hoje as mulheres da terceira idade vivem mais e, por essa razão, tornaram-se numericamente superiores nas faixas etárias relativas à velhice, devemos investigar sobre as mudanças ocorridas nos processos demográficos que levaram a essa inversão. Finalmente, esperamos que este ensaio tenha contribuído com o propósito maior de expor as potencialidades de uma variada documentação tão rica e valiosa para os estudos sobre a velhice nos séculos passados.

\section{Referências}

ARIĖS, Philippe. Une histoire de la vieillesse. Communications, Paris, v. 37, n. 1, p. 47-54, 1983.Disponível em: <http://www.persee.fr/doc/comm_0588-8018_1983_num_37_1_1551>. Acesso em: out. 2017.

BACELLAR, C. de A. P. Os senhores da terra: família e sistema sucessório entre os senhores de engenho do Oeste paulista, 1765-1855. Campinas: CMU/Unicamp, 1997. 
BAZO, Maria T. La nueva sociologia de la vejez: de la teoria a los métodos, Reis - Revista Española de Investigaciones Saciológicas, Madrid, n.60, p. 75-90, out./dez. 1992. Disponível em: < htttp://www.jstor.org/stable/40183681>. Acesso em: out. 2017.

BEAUVOIR, Simone de. A velhice. São Paulo: Difel, 1970.

BRITO, Jolumá. História da cidade de Campinas. São Paulo: Saraiva, 1956. v. 1.

CAMARANO, Ana A.; KANSO, Solange; MELLO, Juliana L. Como vive o idoso brasileiro? In: CAMARANO, Ana Amélia. (Org.). Os novos idosos brasileiros: muito além dos 60? Rio de Janeiro: Ipea, 2004.

CAMARANO, Ana A.; PASINATO, Maria T. Introdução. In: CAMARANO, Ana Amélia. (Org.) Os novosidosos brasileiros: muito além dos 60? Rio de Janeiro: Ipea, 2004.

CELTON, Dora Estela. La población de Córdoba a fines del siglo XVIII. Buenos Aires:Academia Nacional de la Historia, 1993.

COSTA, Dora Isabel P. da. Heranç̧a e ciclo de vida: um estudo sobre familia e população em Campinas, São Paulo (1765-1850). Tese (Doutorado em História) - Universidade Federal Fluminense, Niterói. 1997.

DEBERT, Guita G. A construção e a reconstrução da velhice: família, classe social e etnicidade. In: NERI, Anita L.; DEBERT, Guita C. (Orgs.). Velhice e sociedade. Campinas: Papirus, 1999.

DUBERT, Isidro. Vejez, familia y reproducción social en España, siglos XVIII-XX. Revista de Demografía Histórica, Madrid, v. 26, n. 2, p. 87-122, 2008. Disponível em: <http://www.adeh.org/?q=es/system/files/ Revista/II-2008/DUBERT.pdf>. Acesso em: out. 2017.

EISENBERG, P. Homens esquecidos: escravos e trabalhadores livres no Brasil: séculos XVIII e XIX. Campinas: Unicamp, 1989.

GARCÍA CONZÁLEZ, F. Introducción: Vejez, envejecimiento e historia. La edad como objeto de investigación. In: GARCÍA CONZÁLEZ, F. (Org.). Vejez, envejecimiento y sociedad em España, siglos XVI-XXI. Cuenca: Universidad de Castilla-La Mancha, 2005.

CUSMÃO, Neusa M. M. de. A maturidade e a velhice: um olhar antropológico. In: NERI, Anita L. (Org.). Desenvolvimento e envelhecimento: perspectivas biológicas, psicológicas e sociológicas. Campinas: Papirus, 2001.

KUBO, E. M. Aspectos demográficos de Curitiba, 1801-1850. Dissertação (Mestrado em História) - Universidade Federal do Paraná, Curitiba. 1974.

LACE, Lana. A boa esposa e a mulher entendida. In LACE, Lana (Org.) Mulheres, adúlteros e padres. Rio de Janeiro: Dois Pontos, 1987.

LASLETT, Peter. Necessary knowlwdge: age and aging in the societies of the past. In: KERTZER, David I.; LASLETT, Peter (Orgs.). Aging in the past: Demography, society, and old age. Berkeley: University of California, 1995. p. 3-79.

LOZANO-POVEDA, Diana. Concepción de vejez: entre la biologia y la cultura. Investigación em Enfermería [Imagem y Desarollo], Bogotá, v. 13, n. 2, p. 89-100, jul./dez. 2011. Disponível em: <http://www.redalyc. org/articulo.oa?id=145222559006>. Acesso em: out. 2017. 
MADEIRA, Artur B.; RODRICUES, José D.; MATOS, Paulo L. População e família de uma vila açoriana: as Velas da Ilha de São Jorge (1766-1799). População e Sociedade, Porto, n. 4, p. 59-93, 1998. Disponível em: < http:// www.cepesepublicacoes.pt/portal/pt/obras/populacao-e-sociedade/revista-populacao-e-sociedade-no-4/ populacao-e-familia-de-uma-vila-acoriana-as-velas-da-ilha-de-s-jorge-1766-1799>. Acesso em: out. 2017.

MARCÍLIO, Maria Luiza. Caiçara: terra e população - estudo de demografia histórica e da história social de Ubatuba. São Paulo: Paulinas; Cedhal, 1986.

Crescimento demográfico e evolução agrária paulista: 1700-1836. São Paulo: Hucitec; Edusp, 2000.

MARTINS, Valter. Nem senhores, nem escravos. Campinas: CMU/Unicamp, 1996.

MESQUITA, Eni. O papel do agregado na região de Itu - 1780 a 7830. São Paulo: Museu Paulista da USP, 1977. (Série de História, v. 6, Parte I). p. 10-121.

MOTTA, José Flávio. Velhos no cativeiro: posse e comercialização de escravos idosos. In: ENCONTRO NACIONAL DE ESTUDOS POPULACIONAIS, 16., 2008, Caxambu. Anais.... Caxambu: Associação Brasileira de Estudos Populacionais, 2008. p. 5. (CD-ROM).

O tráfico de escravos velhos (província de São Paulo, 1861-1887). História: Questões \& Debates, Curitiba, v. 27, n. 52, p. 41-73, jan./jun. 2010.

NOZOE, Nelson; COSTA, Iraci del Nero da. Achegas para a qualificação das Listas Nominativas. Estudos Econômicos, São Paulo, v. 21, n. 2, p. 271-284, maio/ago. 1991.

NERI, Anita L. (Org.). Desenvolvimento e envelhecimento: perspectivas biológicas, psicológicas e sociológicas. Campinas: Papirus, 2001.

REHER, David S. Vejez y envejecimiento em perspectiva histórica: retos de um campo em auge. Política y Sociedad, Madrid, v. 26, p. 63-71, 1997. Disponível em: <http://revistas.ucm.es/index.php/POSO/article/ view/POSO9797330063A>. Acesso em: out. 2017.

OTERO, Hernán. Representaciones estadísticas de la vejez. Argentina, 1869-1947. Revista Latinoamericana de Población, Buenos Aires, v. 7, n. 13, p. 5-28, 2013. Disponível em: <http://www.redalyc.org/ pdf/3238/323830085001.pdf>. Acesso em; out. 2017.

PERECALLI, Enrique. Recrutamento militarno Brasil colonial. Campinas: Unicamp, 1986. (Série Teses).

SAMARA, Eni. A família brasileira. 4. ed. São Paulo: Brasiliense, 1993.

SILVA, Maria Beatriz Nizza da. História da Família no Brasil colonial. Rio de Janeiro: Nova Fronteira, 1998.

SIQUEIRA, Maria E. C. de. Teorias sociológicas do envelhecimento. In: NERI, Anita L. (Org.). Desenvolvimento e envelhecimento: perspectivas biológicas, psicológicas e sociológicas. Campinas: Papirus, 2001.

SLENES, Robert W. A formação da família escrava nas regiões de grande lavoura do Sudeste: Campinas, um caso paradigmático no século XIX. População e Família, São Paulo, v. 1, n. 1, jan:/jun. 1998.

TEIXEIRA, Paulo E. O outrolado da família brasileira. Campinas: Unicamp, 2004. 